\title{
Learning Reading Skills Independently Using Interactive Multimedia
}

\author{
Noor Aini Ahmad \\ Department of Special Education, Faculty of Human Development, Sultan Idris Education University, Malaysia
}

Received February 17, 2020; Revised March 31, 2020; Accepted April 7, 2020

Copyright $\bigcirc 2020$ by authors, all rights reserved. Authors agree that this article remains permanently open access under the terms of the Creative Commons Attribution License 4.0 International License

\begin{abstract}
This article presents a need analysis survey result on improving reading skills using interactive multimedia. 46 participants were involved in this study and they were chosen using random sampling. Result shows that there is no significant difference between interactive multimedia and gender by $\mathrm{t}=-.839, \mathrm{p}=.830(\mathrm{p}>.05)$. Result also shows that there was no significant difference between interactive multimedia and school locations with the value of $t=1.05, p=.885(p>.05)$. This finding shows that teachers in urban and rural areas have similar views on developing interactive multimedia learning tools for students with specific learning difficulties. The result of the Pearson correlation test shows a significant $r=.321 *$ value $(\mathrm{p}<.005)$. These results show that students with specific learning difficulties and needs for developing interactive multimedia tools are positive variables and it also shows a strong influence on the teaching and learning process. Thus, interactive multimedia tools will lead to a significant increase in reading skills among students with specific learning difficulties. Recommendations are made related to the needs of developing interactive multimedia learning tools for intervention program. By using interactive multimedia as instructional tools, students with specific learning difficulties will be able to learn independently in more fun environment. As conclusion, teachers need to move together towards evolution in education and implement a more enjoyable and meaningful learning in their instruction using interactive multimedia tools.
\end{abstract}

Keywords Reading Skills, Interactive Multimedia, Students with Specific Learning Difficulties

\section{Introduction}

Children with learning difficulty (and specific learning difficulties) need support (and learning tools) to avoid them from being left behind in education (Holttum, 2016). A common example of students with specific learning difficulties is dyslexia that affects the acquisition of literacy (McDowell, 2018). Children who had problems in reading skills seem to struggle in word recognition, poor in spelling, encounter inability to differentiate phonemes and even colors (Khan, Oon, Haq \& Hajarah, 2018). In current education landscapes, teachers need an appropriate training in identification and assessment practices to help children receive appropriate special education services (Maki \& Adams, 2018). How reading skills and reading difficulties evolve remains controversial until today. Many terms are used to describe a child who shows difficulties in reading skills such as poor reading, low reading ability or reading problems (Lancheros-Cuesta, Carrillo-Ramos \& Pavlich-Mariscal, 2019). Therefore, the current study tries to find out if there is a need to develop interactive multimedia learning tools or kits to improve reading skills among students with specific learning difficulties.

\section{Background of Study}

Children underachieve in academic for a wide range of reasons including many factors, namely genetic, psychological, behavioral and emotional factors. Inadequate curricula and ineffective instruction seem to be partly of the reasons too. They need support and evidence-based instruction (Kluwer, 2018). Children with reading difficulty usually were diagnosed to match the inclusion criteria of words reading, decoding and also fluency ability (Holland, 2015). Reading comprehension, for example, needs a child to decode and comprehend what he or she is reading. If a child cannot understand the printed words, therefore he or she will not be able to understand written language (Nation, 2019). Multimedia has a strong influence in enhancing and optimizes reading skills as it provides opportunities to extend children's respective needs. It also increases children's interest and 
engages their attention in reading activities (Ahmad, Savugathali \& Jeffry, 2018). The fundamental importance to support the current study lays on Taba $(1962,1967)$ whereby we try to design a suitable interactive learning tool based on the diagnostic test result which Taba named as the first inquire step in her theory. This feasibility study was conducted prior to the construction of an interactive multimedia learning tool. We hope to develop an interactive learning tool in order to help students with specific learning difficulties in reading words more effectively.

\section{Problems of Statement}

Adaptable e-learning experiences that are aligned with the preferred learning styles of children can be delivered and adequately fulfill the system requirements with its suitability and effectiveness (Alsobhi \& Alyoubi, 2019). Slow reading could be the result of slow representations in activation of phonological or difficulties in achieving orthographic or due to many other reasons (Cuetos, 2015). Poor readers find it difficult to learn new words accurately, they find it difficult in phonological recoding or decoding, sight word reading or some might have problems in visual word recognition (McArthur \& Castles, 2017). This problem can be detected through screening and diagnostic test. Relevant learning tools using interactive multimedia might help them to learn to read independently.

\section{Literature Review}

\section{Specific Learning Disabilities}

In mainstream settings, there are certainly students who are far behind from their peers due to specific learning disabilities (Polat, Cagiltay, Aykut \& Karasu, 2019). Students with specific learning disabilities can be described as specific developmental disabilities of academic skills such as reading, writing and mathematics (Kholoud Adeeb Al-Dababneh, 2018). Students with specific learning disabilities usually are not interested and not engaged in classroom tasks or they show externalizing behaviors when asked to practice reading, writing or counting (McGovern, Lowe \& Hill, 2016). They need support and suitable learning tools to learn reading skills more effectively.

\section{Reading Skills}

A child is at risk for not achieving minimum reading fluency when they are in the middle of second grade, and a deficit in sight vocabulary is likely the cause of the fluency problem too (Morris \& Perney, 2018). Children who are poor to comprehend and poor in decoding will struggle with sentence structure, constructed sentences and usually they will have problems with writing skills, grammar and story organization (Herbert, Massey-Garrison \& Geva, 2019). Children need to have more opportunity to read. Knowledge in reading is usually influenced by environment, social and cognitive factors (Ahmad, 2017) and teachers' competency is also an important factor to avoid misunderstandings while learning (Goh \& Wong, 2014). Thus, environment and the instructional setting have a significant impact on children's learning goals, motivated behavior and attitudes (Kormos, 2017). The ability to communicate and ascertain how much information is shared usually relies on general understanding of social interaction, functioning language and the capacity of specific context of the communication (Cardillo, Garcia, Mammarella \& Cornoldi, 2018). All these factors when blended together will support reading instructions to students with specific learning difficulties.

\section{Interactive Multimedia}

Technology can positively facilitate teachers' abilities in instructions and interventions for children with disabilities (Alsobhi \& Alyoubi, 2019). Knowing the way to motivate children effectively, using information technology can be very useful for teachers who teach children with learning difficulties (Tang \& Zhang, 2018). Educational technology is a promising intervention approach in terms of meeting the needs and ability of children with learning disabilities (Polat, Cagiltay, Aykut \& Karasu, 2019). Gamification is also a way to attract and improve the engagement of children (Zeng, Tang \& Wang, 2017). During reading instruction to children with weak working memory and difficulties with rapid processing of information, teachers need to move towards using digital and interactive multimedia in the classroom (Ahmad \& Khoo, 2019). Students developed their reading skills through interactive multimedia as it supports positive learning reading experiences in the classroom and at home (Ahmad \& Rosmanizam, 2017). Interactive multimedia offers a better chance in education especially to children who are slow in reading.

\section{Methodology}

This study uses survey as research method. A total of 46 Special Education teachers were employed randomly as samples. The questionnaire was designed using the format of: 5-Strongly agree, 4- Agree, 3- Neutral, 2- Disagree and 1-Strongly Disagree. The Average Variance Extracted (AVE) value $=0.53$, which was adequate for convergent validity (Hair, Hult, Ringle \& Sarstedt, 2014). The average composite reliability value of the internal consistency in scale items was 0.83 . According to Nunnally \& Bernstein (1994), the acceptable composite reliability value is between 0.60 to 0.89 and it is not desirable if the value is more than 0.90 . 


\section{Results}

Table 1. Content Differences on Interactive Multimedia by Gender

\begin{tabular}{cccccc}
\hline Gender & $\mathrm{n}$ & mean & $\mathrm{SD}$ & $\mathrm{t}$-value & $\mathrm{p}$ \\
\hline Male & 6 & 3.97 & .608 & -.839 & .830 \\
Female & 40 & 4.16 & .496 & & \\
\hline
\end{tabular}

$\mathrm{P}<.05$

Table 1 shows that there were no significant differences of the interactive multimedia by $\mathrm{t}=-.839, \mathrm{p}=.830(\mathrm{p}>.05)$. This shows that male teachers and female teachers have similar opinions about the interactive multimedia. Thus, $\mathrm{Ho}_{1}$ : there is no significant difference in the content of the interactive multimedia learning tools based on gender was accepted.

Table 2. Correlation on Interactive Multimedia by School Locations

\begin{tabular}{cccccc}
\hline School Location & $\mathrm{n}$ & mean & $\mathrm{SD}$ & $\mathrm{t}$-value & $\mathrm{p}$ \\
\hline Urban & 25 & 4.21 & .489 & 1.05 & .885 \\
Rural & 21 & 4.05 & .529 & & \\
\hline
\end{tabular}

$\mathrm{P}<.05$

Table 2 shows that there were no significant differences of the interactive multimedia by school locations with a value of $\mathrm{t}=1.05, \mathrm{p}=.885(\mathrm{p}>.05)$. This finding shows that teachers in urban and rural areas have similar views on the interactive learning tools. Thus, $\mathrm{Ho}_{2}$ : there is no significant difference in the interactive multimedia learning tools based on school locations was accepted.

Table 3. Correlation Test between Students' Needs with Interactive Multimedia

\begin{tabular}{ccc}
\hline & & Interactive multimedia \\
\hline \multirow{3}{*}{ Students' needs } & $\mathrm{r}$ & $.321^{*}$ \\
& Sig. & .030 \\
& (2-tailed) & 46 \\
\hline
\end{tabular}

** Significant correlation level 0.05 (2-tailed)

Table 3 illustrates the finding of the Pearson correlation test with a significant $\mathrm{r}=.321 *$ value $(\mathrm{p}<.005)$. These results show that students' needs and interactive multimedia are positive variables and have a strong influence on the reading skills of teaching and learning process. The use of interactive multimedia will lead to a significant increase among students with specific learning difficulties. Therefore, $\mathrm{Ho}_{3}$ : there was no significant relationship between the students' needs and the interactive multimedia was rejected.

\section{Discussion}

There are many reasons why children may be slow or unable to master reading skills (Cuetos, 2015; McArthur \&
Castles, 2017). In today's educational world, there are many technologies suitable in the classroom including interactive multimedia. Interactive multimedia is a support and evidence-based instruction (Kluwer, 2018) that can increase children's ability to read, decoding and also fluency ability (Holland, 2015) and increase children's interest and engage their attention in reading activities (Ahmad, Savugathali \& Jeffry, 2018). Current study finds that teachers strongly agreed that students need interactive learning tools to learn reading skills and it has a strong influence in teaching and learning process. They also agreed that interactive multimedia will increase students' interest and motivation towards reading activities. However our study has several limitations such as it only focus on learning tools in reading skills for students with specific learning difficulties. To facilitate reading skills and develop interactive multimedia learning tools, we also need to consider support and strong effort for the efficacy of the activities.

\section{Conclusion and Recommendation}

Reading skills are critical factors for success of many children at school, regardless of their disabilities. We must consider to look into whether there are issues present in early indicators during early grades, and we must also see how these predictors may change over time as it will help us to understand the connection between reading skills and the use of interactive multimedia in classrooms and at home. This article recommends the use of interactive multimedia learning tools that consist of picture cards that can be triggered with augmented reality techniques and three dimensional books to attract children with specific learning difficulties to read. These recommendations are made related to the high needs among teachers on interactive multimedia learning tools in intervention program for children with specific learning difficulties and also children with disabilities.

\section{Acknowledgments}

This grant work was supported by The Malaysia Ministry of Higher Education, Universiti Pendidikan Sultan Idris (UPSI), the Research Management and Innovation Centre of UPSI and the Faculty of Human Development, UPSI, through GPUBP Phase 1/2019: 2019-0076-107-01 and 2019-0134-106-02 (FRGS/1/2019/SS04/UPSI/02/1)

\section{REFERENCES}

[1] Ahmad, N. A., \& Khoo, Y.Y. (2019). Using interactive 
media to support reading skills among underachiever children. International Journal of Innovation, Creativity and Change, 8(7), 81-88.

[2] Ahmad, N. A., \& Rosmanizam, S.C.L. (2017). Interactive multimedia activities using augmented reality to promote reading and writing skills amongst young children. Journal of Teaching and Education, 6(2), 193-198.

[3] Ahmad, N. A., Savugathali, A. F., \& Jeffry, Y. (2018). Engaging and facilitating learning language skills via multimedia systems amongst at-risk students. Journal of Teaching and Education, 5(2), 87-94.

[4] Ahmad, N.A. (2017). Engaging and facilitating language skills using augmented reality as a medium of learning and teaching. Journal of Teaching and Education, 06(02), $133-138$

[5] Ahmad, N.A. (2018). Learning literacy using augmented reality (LitAR): an application of learning through expository, social and technical-scientific using augmented reality as learning strategy. International Journal of Academic Research in Business and Social Sciences, 8(11), 1772-1778.

[6] Alsobhi, A.Y., \& Alyoubi, K.H. (2019). Adaptation algorithms for selecting personalized learning experience based on learning style and dyslexia. Data Technologies and Applications, 53(2), 189-200.

[7] Cardillo, R., Garcia, R. B., Mammarella, I.C., \& Cornoldi, C. (2018). Pragmatics of language and theory of mind in children with dyslexia with associated language difficulties or nonverbal learning disabilities. Applied Neuropsychology Child, 7(3), 245-256.

[8] Cuetos, F. (2015). Reading difficulties in Spanish adults with dyslexia. Annal of Dyslexia, 65, 33-51.

[9] Goh, P.S.C., \& Wong, K.T. (2014). Discerning beginning teachers' conceptions of competence through a phenomenographic investigation. Journal of Research, Policy \& Practice of Teachers and Teacher Education, 4(1), 40-47.

[10] Hair, J., Hult, G. T. M., Ringle, C., \& Sarstedt, M. (2014). A Primer on Partial Least Squares Structural Equation Modeling (PLS-SEM). Los Angeles: SAGE Publications.

[11] Herbert, K. E. D., Massey-Garrison, A., \& Geva, E. (2019). A developmental examination of narrative writing in EL and ELL school children who are typical readers, poor decoders or poor comprehenders. Journal of Learning Disabilities, 53(1), 1-12.

[12] Holland, S.K. (2015), Greater functional connectivity between reading and error-detection regions following training with the reading acceleration program in children with reading difficulties. Ann. of Dyslexia, 65, 1-23.

[13] Holttum, S. (2016). Dyslexia: is it genetic and what does this mean for social inclusion? Emerald Group Publishing Limited, 20(4), 202-207.

[14] Khan, R. H., Oon, Y. B., Haq, M. I. U \& Hajarah, S. (2018). Proposed user interface design criteria for children with dyslexia. International Journal of Engineering \& Technology, 7 (4), 5253-5257.

[15] Kholoud Adeeb Al-Dababneh (2018). Barriers preventing parental involvement in mainstream education of children with specific learning disabilities: parent perspectives. European Journal of Special Needs Education, 33(5), 615-630.

[16] Khoo, Y. Y., Ahmad, N. A., Zakariya, Z., Abdul Razak, A., \& Yap, S. Y. P. (2019). An exploratory study in using music videos among pre-service teachers: sing along with economics concepts. Universal Journal of Educational Research, 7(9), 2003-2007.

[17] Kluwer, W. (2018), Specific learning disabilities: issues that remain unanswered, Indian Psychiatric Society, 40(5), 399-405.

[18] Kormos, J. (2017). The Effects of Specific Learning Difficulties on Processes of Multilingual Language Development. Cambridge University Press, 37, 30-44.

[19] Lancheros-Cuesta, D., Carrillo-Ramos, A., \& Pavlich-Mariscal, J. A. (2019). Kamachiy-Mayistru: adaptive module to support teaching to people with learning difficulties. Emerald Group Publishing Limited,11(4), 510-526.

[20] Maki, K.A., \& Adams, S.R. (2018). Current landscape of specific learning disability identification: training, practices and implications. Wiley Periodicals Inc, 2019(56), 18-31.

[21] McArthur, G., \& Castles, A. (2017), Helping children with reading difficulties: some things we have learned so far. NJP Science of Learning, 2(7), 1-4.

[22] McDowell, M. (2018). Specific learning disability. Journal of Paediatrics and Child Health, 54 1077-1083.

[23] McGovern, J. C., Lowe, P. A., \& Hill, J. M. (2016). Relationships between trait anxiety, demographic variables, and school adjustment in students with specific learning disabilities. Journal of Child and Family Studies, 25, 1724-1734.

[24] Morris, D., \& Perney, J., (2018). Using a sight word measure to predict reading fluency problems in Grades 1 to 3. Reading \& Writing Quarterly, 34(4), 338-348.

[25] Nation, K. (2019), Children's reading difficulties, language, and reflections on the simple view of reading. Australian Journal of Learning Difficulties, 24(1) 47-73.

[26] Nunnally, J. C., \& Bernstein, I. H. (1994). Psychological theory. New York: MacGraw-Hill.

[27] Polat, E., Cagiltay. K., Aykut. C.. \& Karasu. N. (2019). Evaluation of a tangible mobile application for students with specific learning disabilities. Australian Journal of Learning Difficulties, 24(1), 95-108.

[28] Taba, H. (1962). Curriculum development: Theory and practice. New York: Harcourt Brace.

[29] Taba, H. (1967). Teacher's handbook for elementary social studies. Reading, MA: Addison Wesley.

[30] Tang, J.. \& Zhang, P. (2018). Exploring the relationships between gamification and motivational needs in technology design. International Journal of Crowd Science, 3(1), 87-103.

[31] Thompson, P. A., Hulme, C., Nash, H. M., Gooch, D., Hayiou-Thomas, E., \& Snowling, M. J. (2015). 
Developmental dyslexia: predicting individual risk. Journal of Child Psychology and Psychiatry, 56(9), 976-987.

[32] Wormald, C, B., Rogers. K., \& Vialle, W. (2015). A case study of giftedness and specific learning disabilities: bridging the two exceptionalities. Roeper Review, 37(3), 124- 138.

[33] Zeng, Z., Tang, J., \& Wang, T. (2017). Motivation mechanism of gamification in crowd sourcing projects. International Journal of Crowd Science, 1(1), 71-82. 